\section{Allergy \\ Immunology}

Int Arch Allergy Immunol 2006;140:252-260

DOI: $10.1159 / 000093251$
Received: September 28, 2005

Accepted after revision: January 18, 2006

Published online: May 10, 2006

\title{
Response of Respiratory Flour Allergics in an Ingested Flour Challenge May Involve Plasmacytoid Dendritic Cells, CD25+ and CD152+ T Cells
}

\author{
Hans Jürgen Hoffmann ${ }^{a}$ Tina Skjold $^{a}$ Martin Raithel $^{b}$ Katja Adolf $^{\mathrm{a}}$ \\ Ole Hilberg $^{a}$ Ronald Dahl ${ }^{a}$ \\ ${ }^{a}$ Department of Respiratory Diseases, Aarhus University Hospital, Aarhus, Denmark; \\ ${ }^{b}$ Department of Medicine I, University of Erlangen-Nürnberg, Erlangen, Germany
}

\section{Key Words}

Basophils $\cdot \mathrm{N}$-methyl histamine $\cdot$ Occupational wheat

allergy $\cdot$ DBPCFC $\cdot$ pDC $\cdot$ CD 4+CD25+ T reg

\begin{abstract}
Background: A number of occupational respiratory allergens are food related, and little is known about the responses these allergens elicit in sensitized persons that ingest them. Methods: Nine respiratory flour-allergic volunteers were exposed in a double-blind placebocontrolled food challenge with flour. Responses were monitored by spirometry, acoustic rhinometry, determination of urinary methyl histamine and tryptase and flow cytometric evaluation of basophil, dendritic and T cell numbers and markers. Results: Significant increases in serum tryptase (compared with placebo post-exposure levels) and methyl histamine and a coordinated decrease in blood basophils and nasal volume after ingestion of allergen compared with placebo suggest an allergic response to ingested allergen. There was no change in forced expiratory volume in $1 \mathrm{~s}$. The number of blood plasmacytoid dendritic cells (DC), but not of myeloid DC, decreased after exposure $(p=0.001)$. DC HLA DR was reduced after both exposures $(p<0.001)$. Expression of CXCR4 on DC was reduced after allergen $(p=0.033)$ but not after placebo exposure. CD4+ T cell expression of
\end{abstract}

CD25 was elevated after placebo $(p=0.021)$ but reduced after allergen provocation. The reduction in CD25 expression after allergen compared with placebo was significant $(p=0.024)$. CD152 was downregulated on these cells after allergen $(p=0.039)$ but less so after placebo exposure. Conclusion: Persons with respiratory allergy respond after ingestion of the relevant allergen. Response to this allergen challenge may selectively recruit plasmacytoid DC through CXCR4 and T cells expressing CD25 and CD152, which may be a regulatory phenotype.

Copyright $(2006$ S. Karger AG, Basel

\section{Introduction}

Bakers' asthma covers allergy to wheat (prevalence $3.6 \%$ ), rye and $\alpha$-amylase (prevalence $1.0 \%$ ) [1]. However, little is known about the responses raw ingested baker allergens elicit in sensitized persons, and bakers sensitized to raw bakery allergens can safely ingest cooked or baked allergens [2]. Gastrointestinal allergy to wheat may be underdiagnosed as it may be concealed by irritable bowel disease [3]. It is known that cross-reacting allergens found in fruit and nuts can elicit gastrointestinal and oral symptoms in persons allergic to pollen [4], and respiratory latex allergy is associated with reactions to several

\section{KARGER}

Fax +41613061234 E-Mail karger@karger.ch www.karger.com

\section{(C) 2006 S. Karger AG, Basel}

1018-2438/06/1403-0252\$23.50/0

Accessible online at:

www.karger.com/iaa
Correspondence to: Dr. Hans Jürgen Hoffmann

Department of Respiratory Diseases, Aarhus University Hospital

Building 2b, Nørrebrogade 44

DK-8000 Aarhus (Denmark)

Tel. +458949 2107, Fax +458949 2110, E-Mail hjhof@as.aaa.dk 
Table 1. Demographic description of participants and challenge doses for allergen and placebo

\begin{tabular}{|c|c|c|c|c|c|c|c|c|c|}
\hline $\begin{array}{l}\mathrm{Pa}- \\
\text { tient }\end{array}$ & $\begin{array}{l}\text { Age/ } \\
\operatorname{sex}\end{array}$ & $\begin{array}{l}\text { Time since } \\
\text { WP exposure } \\
\text { years }\end{array}$ & $\begin{array}{l}\text { Smoking } \\
\text { years }\end{array}$ & Diagnosis & $\begin{array}{l}\text { PD20 } \\
\text { methacholine } \\
\mu \mathrm{g}\end{array}$ & $\begin{array}{l}\text { Sensitization, prick test or } \\
\text { specific IgE }\end{array}$ & Medication & $\begin{array}{l}\text { Wheat } \\
\text { dose, g }\end{array}$ & $\begin{array}{l}\text { Maize } \\
\text { dose, } g\end{array}$ \\
\hline 1 & $41 \mathrm{M}$ & 4 & none & asthma & $>11,520$ & $\begin{array}{l}\text { wheat, rye, barley, oat, } \alpha \text {-amylase, } \\
\text { grass, mugwort, } D \text {. pteronyssimus, } \\
\text { D. farinae, cockroach, flour moth, } \\
\text { L. destructor, A. siro }\end{array}$ & none & 80.5 & 80.5 \\
\hline 2 & $29 \mathrm{M}$ & current & 4 & $\begin{array}{l}\text { asthma/ } \\
\text { rhinitis }\end{array}$ & 641 & $\begin{array}{l}\text { wheat, barley, oat, grass, birch, dog, } \\
\text { cat, D. pteronyssimus, T. putrescentiae }\end{array}$ & $\begin{array}{l}\text { ICS, LABA, } \\
\text { SABA prn }\end{array}$ & 80.5 & 80.5 \\
\hline 3 & $37 \mathrm{M}$ & current & 7 & rhinitis & $>11,520$ & $\begin{array}{l}\text { wheat, rye, barley, birch, } \\
\text { T. putrescentiae }\end{array}$ & none & 80.5 & 80.5 \\
\hline 4 & $38 \mathrm{~F}$ & 2 & none & rhinitis & $>11,520$ & wheat, $T$. putrescentiae & none & 80.5 & 55.5 \\
\hline 5 & $33 \mathrm{~F}$ & none & none & rhinitis & 179.90 & $\begin{array}{l}\text { wheat, rye, barley, oat, grass, birch, } \\
\text { cat, D. pteronyssimus, T. putrescentiae, } \\
\text { L. destructor }\end{array}$ & $\begin{array}{l}\text { ICS, LABA, } \\
\text { NCS, } \\
\text { SABA prn }\end{array}$ & 68.0 & 80.5 \\
\hline 6 & $34 \mathrm{~F}$ & none & none & rhinitis & $>11,520$ & wheat, grass, mugwort & $\begin{array}{l}\text { mesalazin } \\
\text { (ulcerative colitis) }\end{array}$ & 68.0 & 43.0 \\
\hline 7 & $38 \mathrm{~F}$ & 3 & none & $\begin{array}{l}\text { asthma/ } \\
\text { rhinitis }\end{array}$ & 3,859 & wheat, rye, barley, oat & $\begin{array}{l}\text { ICS, LABA, } \\
\text { SABA prn }\end{array}$ & 80.5 & 80.5 \\
\hline 8 & $26 \mathrm{M}$ & current & 7 & rhinitis & $>11,520$ & $\begin{array}{l}\text { wheat, rye, cat, } D . \text { pteronyssimus, } \\
\text { D. farinae, Alternaria, Cladosporium }\end{array}$ & oral AH prn & 80.5 & 80.5 \\
\hline 9 & $24 \mathrm{~F}$ & current & none & $\begin{array}{l}\text { asthma/ } \\
\text { rhinitis }\end{array}$ & 196.89 & $\begin{array}{l}\text { wheat, rye, barley, oat, grass, birch, } \\
\text { mugwort, D. pteronyssimus, D. farinae }\end{array}$ & $\begin{array}{l}\text { ICS, LABA, } \\
\text { NCS, } \\
\text { SABA prn, oral } \\
\text { AH prn }\end{array}$ & 80.5 & 80.5 \\
\hline
\end{tabular}

ICS = Inhaled corticosteroids; LABA = long-acting $\beta_{2}$-agonists; SABA = short-acting $\beta_{2}$-agonists; prn = pro re nata, as necessary; NCS = nasal corticosteroids; $\mathrm{AH}=$ antihistamines.

${ }^{1}$ Time since WP exposed indicates the time elapsed since bakers were exposed at their workplace. None means that the person is not a baker, current means that the person still works in a bakery.

fruit [2]. As the gastrointestinal response can be limited by immunotherapy against cross-reacting respiratory allergens, responses to allergens do occur in different organs [5].

As an allergic reaction is an adaptive response of the immune system, it is likely to be initiated by antigen-presenting cells and activated T cells. Plasmacytoid dendritic cells (pDC) have recently been implicated in initiation of the allergic response in the nose [6] and may be well suited to locally amplify the effector function of $\mathrm{T}$ cells. Additionally, activated and regulatory $\mathrm{T}$ cells expressing CD25 and CD152 [7] are thought to respond by leaving the circulation in response to ingestion of an allergen.

We exposed 9 wheat-allergic persons with respiratory allergy in an oral double-blind placebo-controlled food challenge (DBPCFC) with wheat. Symptoms as well as objective measurements - spirometry, acoustic rhinometry, N-methyl histamine (NMH), blood basophil numbers and serum tryptase - were recorded. In addition, activation of the adaptive immune system was monitored by flow cytometric surface phenotyping.

\section{Methods}

Wheat-allergic persons were selected from hospital files and recruited by mail. The Ethics committee of Århus County approved the project. Responders were screened by telephone and attended the clinic for up to three visits: visit 1 was to confirm the diagnosis, and visits 2 and 3 were components of a DBPCFC [8]. Inclusion criteria were age between 18 and 60 years, positive skin prick test or elevated specific IgE for wheat and documented asthma or rhinitis when exposed to inhaled relevant allergen. Nine persons were included. The demographic data are shown in table 1 . The mean age was $33 \pm 5.8$ years and 4 participants were men. Seven participants had diagnosed rhinitis and 5 had diagnosed asthma. Three patients had both asthma and rhinitis.

Visits 2 and 3 were randomized exposures at least 2 weeks apart to either allergen (commercial wheat flour) or placebo (maize starch), given in blackcurrant juice. Four doses of allergen $(0.5,5$, 25 and $50 \mathrm{~g}$ ) were given at 30 -min intervals. Immediately preceding ingestion of a dose (or $30 \mathrm{~min}$ after a dose that gave rise to symptoms), lung function, i.e. forced expiratory flow in $1 \mathrm{~s}\left(\mathrm{FEV}_{1}\right)$ and forced vital capacity (FVC) [9], and acoustic rhinometry [10] were measured. Blood samples (serum and heparinized blood) were taken before and $30 \mathrm{~min}$ after ingestion of the last dose tolerated. Subjective symptoms were recorded. Spot urine of the last 8 participants was collected at baseline and a 24-hour urine sample after provocation. 


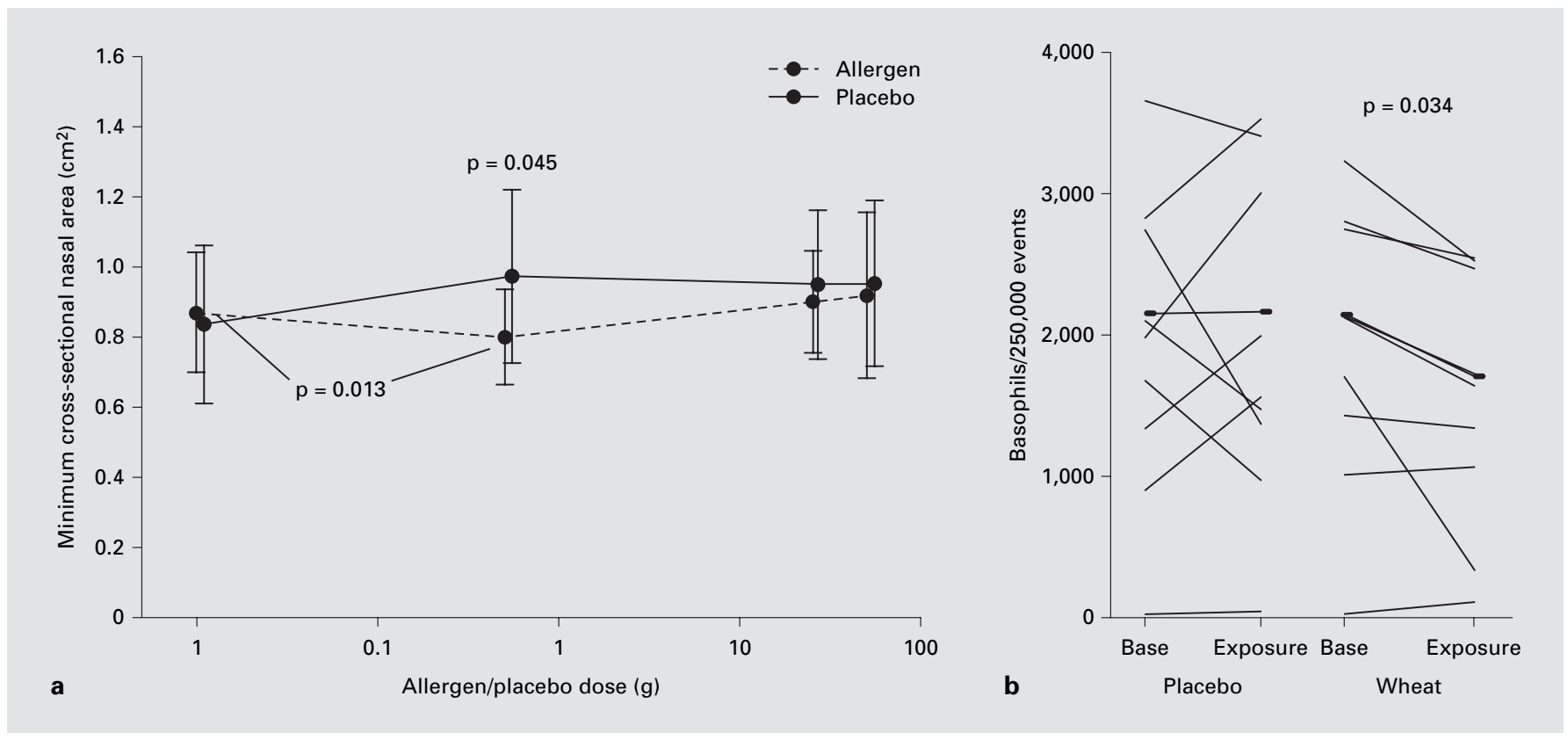

Fig. 1. Markers associated with the allergic response significantly differentiate between allergen and placebo provocation. Significant changes are indicated in each figure. a Changes in the minimal cross-sectional nasal area assessed by rhinometry before each provocation. b Numbers of Lin1- HLA DR- CD123+ basophils per 250,000 events detected by flow cytometry.

Heparinized blood was hemolyzed and labeled with titrated amounts of antibodies: Lin 1 FITC (Cat. Nr. 340546, Becton-Dickinson, Brøndby, Denmark), which comprises antibodies against lineage markers CD3, CD14, CD16, CD19, CD20 and CD56, CD123 phycoerythrin (PE) (Cat. Nr. 340545, Becton-Dickinson), which binds the interleukin-3 receptor, anti-HLA DR PerCP (Cat. Nr. 347364, Becton-Dickinson), CD11 a PE (Cat. Nr. 30425x, Becton-Dickinson), which binds an integrin used to differentiate MT1 and MT2 cells [11], CD62L FITC (Cat. Nr. 1231, Immunotech, Hileah, Fla., USA), CD11c PE (Cat. Nr. 30425x, Becton-Dickinson), which binds an integrin expressed selectively on myeloid dendritic cells (mDC), CD45RA PE Cy5 (Cat. Nr. MCA1720, Serotec, Kidlington, UK), which differentiates between memory and naïve T cells, CD4 allophycocyanin (APC) (Cat. Nr. 30159x, BectonDickinson), which defines CD4 T cells, CD3 APC (Cat. Nr. 555335 , Becton-Dickinson), which defines T cells, CD25 FITC (Cat. Nr. MCA1319F, Serotec),which defines the interleukin-2 receptor, CD152 PE (Cat. Nr. 34585x, Becton-Dickinson), which binds to CTLA4 [7], CD4 PE Cy5 (Cat. Nr. MCA1565C, Serotec), CD45RO APC (Cat. Nr. 340438, Becton-Dickinson), which differentiates between memory and naïve T cells, CXCR4 PE (Cat. Nr. FAB173P, R\&D Systems, Abingdon, UK), which binds to the CXCR4 receptor, and CD14 APC (Cat. Nr. 555399, Becton-Dickinson), which binds to the lipopolysaccharide receptor and defines monocytes; then, they were washed and 250,000 events were acquired with a FACS Calibur (Becton-Dickinson). To evaluate cell numbers, the number of events in the basophil, pDC or $\mathrm{mDC}$ gates were related to all events collected $(250,000)$. This was the level of evidence possible, as leukocyte counts were not available for all participants.
Data were analyzed offline in batch with FlowJo 6.2 (Treestar, Ashland, Oreg., USA). Tryptase was analyzed by fluorometry with UNICap (Pharmacia, Uppsala, Sweden), with a detection limit of $1 \mathrm{ng} / \mathrm{l}$. NMH was analyzed by RIA (Pharmacia) [12].

Data were analyzed with the $t$ test, given as mean \pm SD and displayed as mean \pm SD plots, or the Wilcoxon signed rank test, given as median and interquartile range (IQR) and displayed as box plots, depending on the type of distribution. Baseline was compared with exposure. Baseline values of allergen and placebo exposures were compared to confirm that values were similar, and to expose values to test for a challenge effect. Pearson's correlation coefficient was calculated to determine an association between the changes observed. The level of statistical significance was $\mathrm{p}=0.05$.

\section{Results}

\section{Rhinometry, Blood Basophils, Serum Tryptase and Urinary NMH Differentiate between Ingested Allergen and Placebo}

Four participants reported symptoms when challenged with allergen, whereas 5 participants reported symptoms when challenged with placebo. The difference was not significant (data not shown). As provocation was discontinued after symptoms were recorded, the total dose varied (table 1). Response of participants was evaluated by 

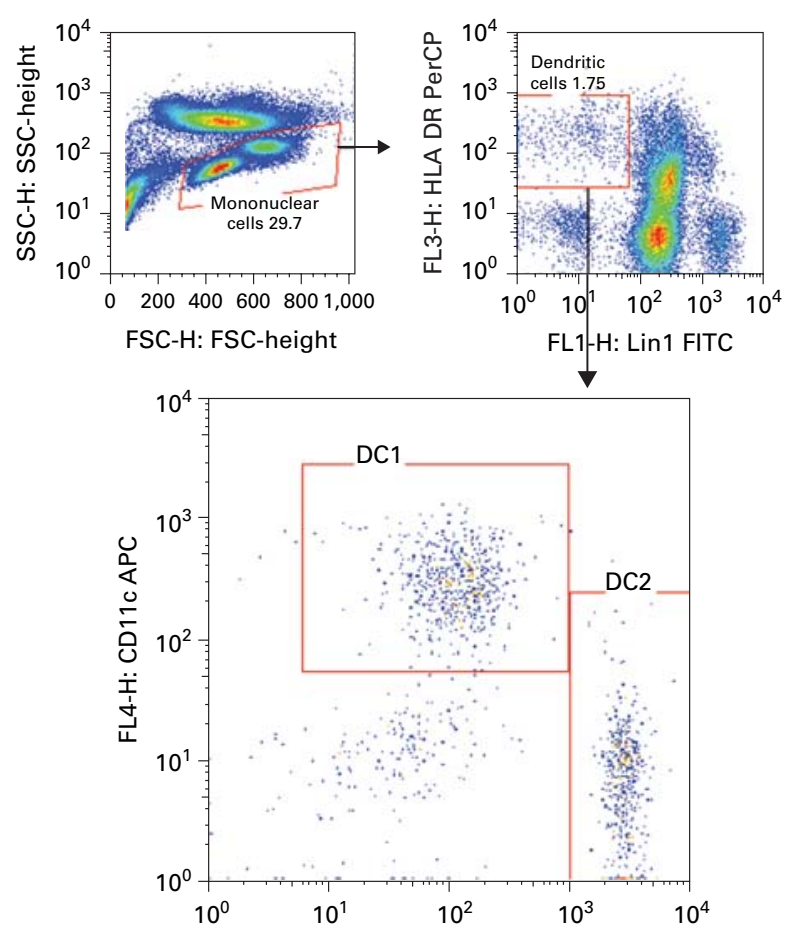

a

FL2-H: CD123 PE
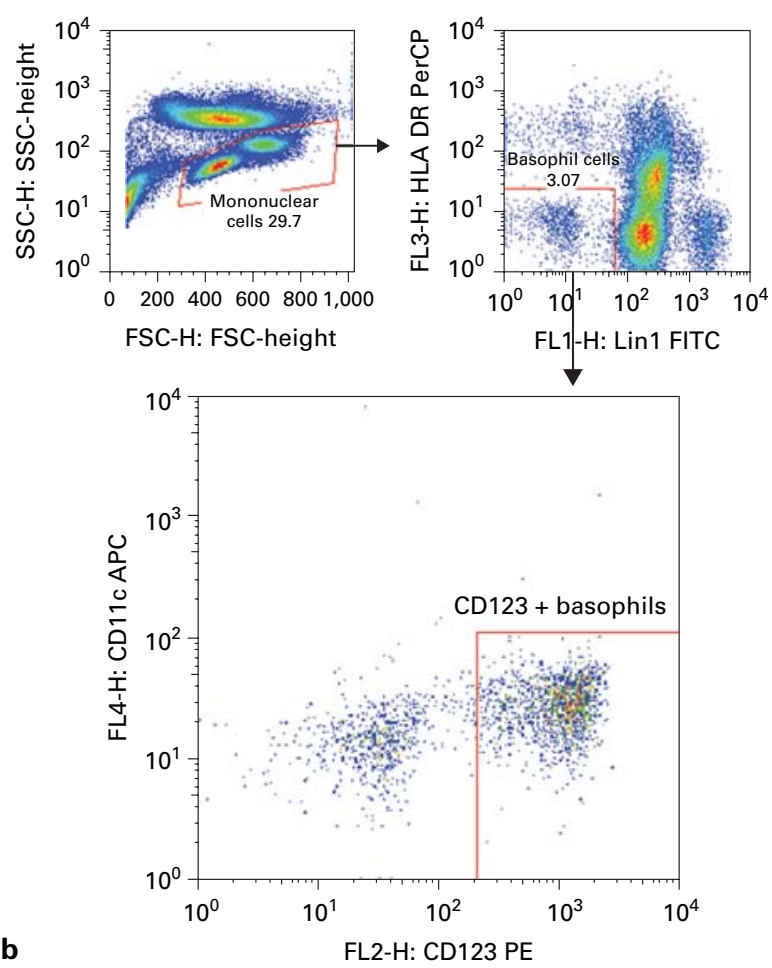
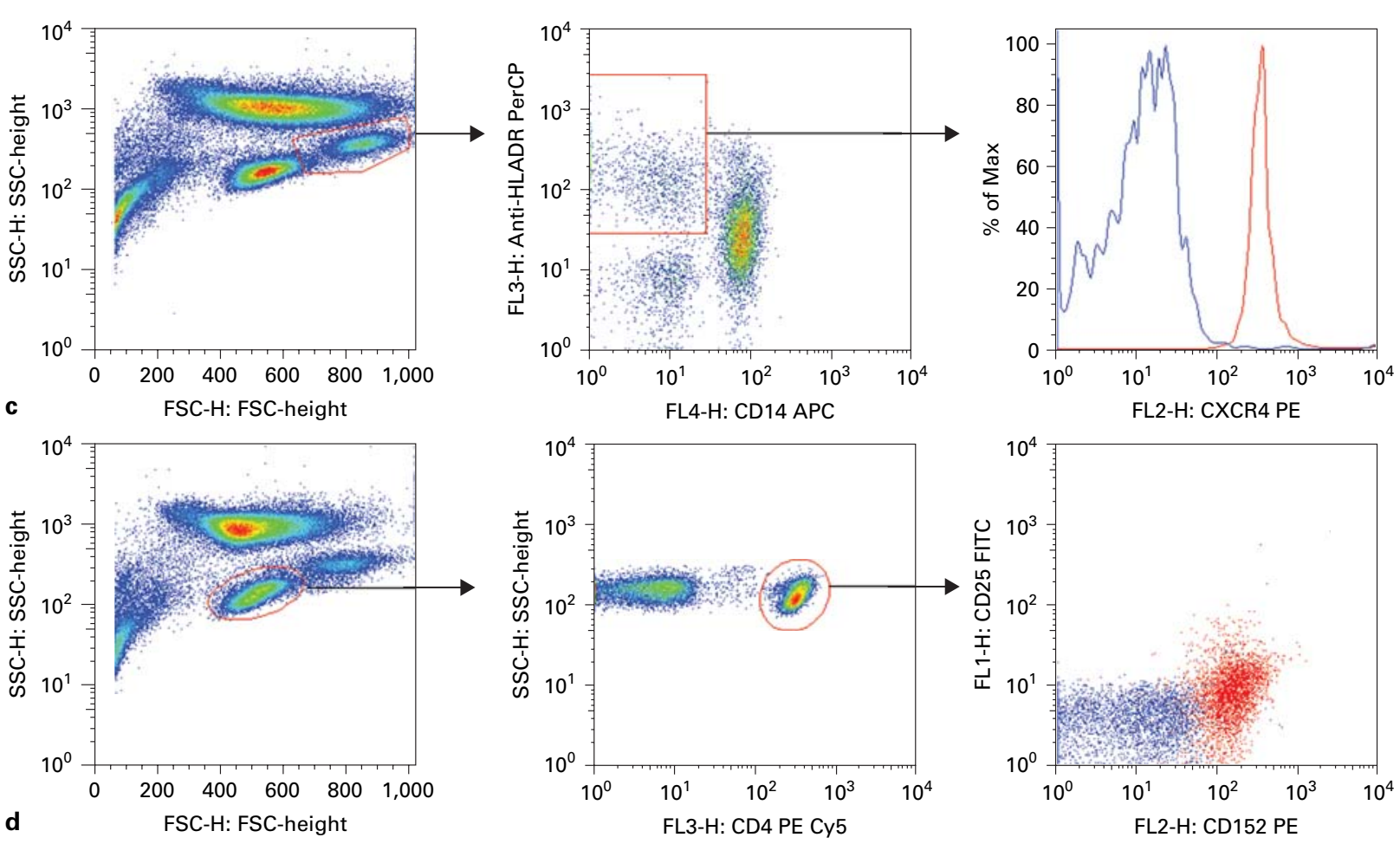

Fig. 2. Flow cytometric identification of basophils, DC and evaluation of surface markers. a Identification of basophil granulocytes as Lin 1- HLA DR-CD11c-CD123 bright cells. b Identification of $\mathrm{mDC}$ and $\mathrm{pDC}$ as Lin1- HLA DR+ CD11 $\mathrm{c}^{\text {bright }} \mathrm{CD} 123^{\mathrm{dim}}$ and
Lin 1- HLA DR + CD11 ${ }^{\text {dim }}$ CD $123^{\text {bright }}$ cells, respectively. c Identification of DC as CD14- HLA DR+ cells and expression of CXCR4 (red) and isotype (blue). d Expression of CD25 and CD152 (red dots) on CD4+ T cells compared with isotype (blue). 

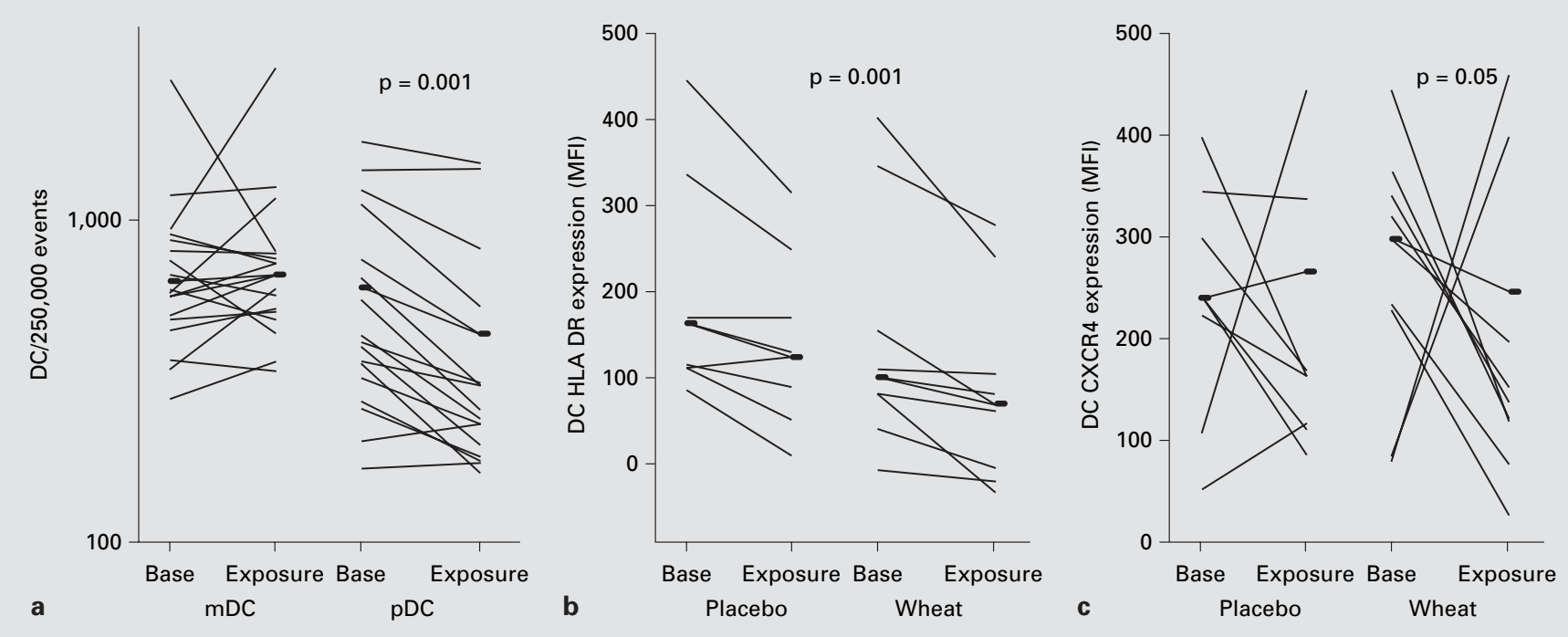

Fig. 3. DC markers suggest that there is an activation of the adaptive immune system during provocation and that CXCR4 expression on DC is associated with the allergic response. a Number of mDC (Lin1- HLA DR+ CD11 ${ }^{\text {bright }}$ CD123 ${ }^{\text {dim }}$ ) and pDC (Lin1- HLA DR+ CD11 ${ }^{\text {dim }}$ CD123 $3^{\text {bright }}$ ) detected before and after exposure. b Decrease in HLA DR expression on CD14- HLA DR+ DC, a sign of tolerization. c Change in expression of the chemokine receptor CXCR4, associated with the allergic response, on CD14- HLA DR+ DC.

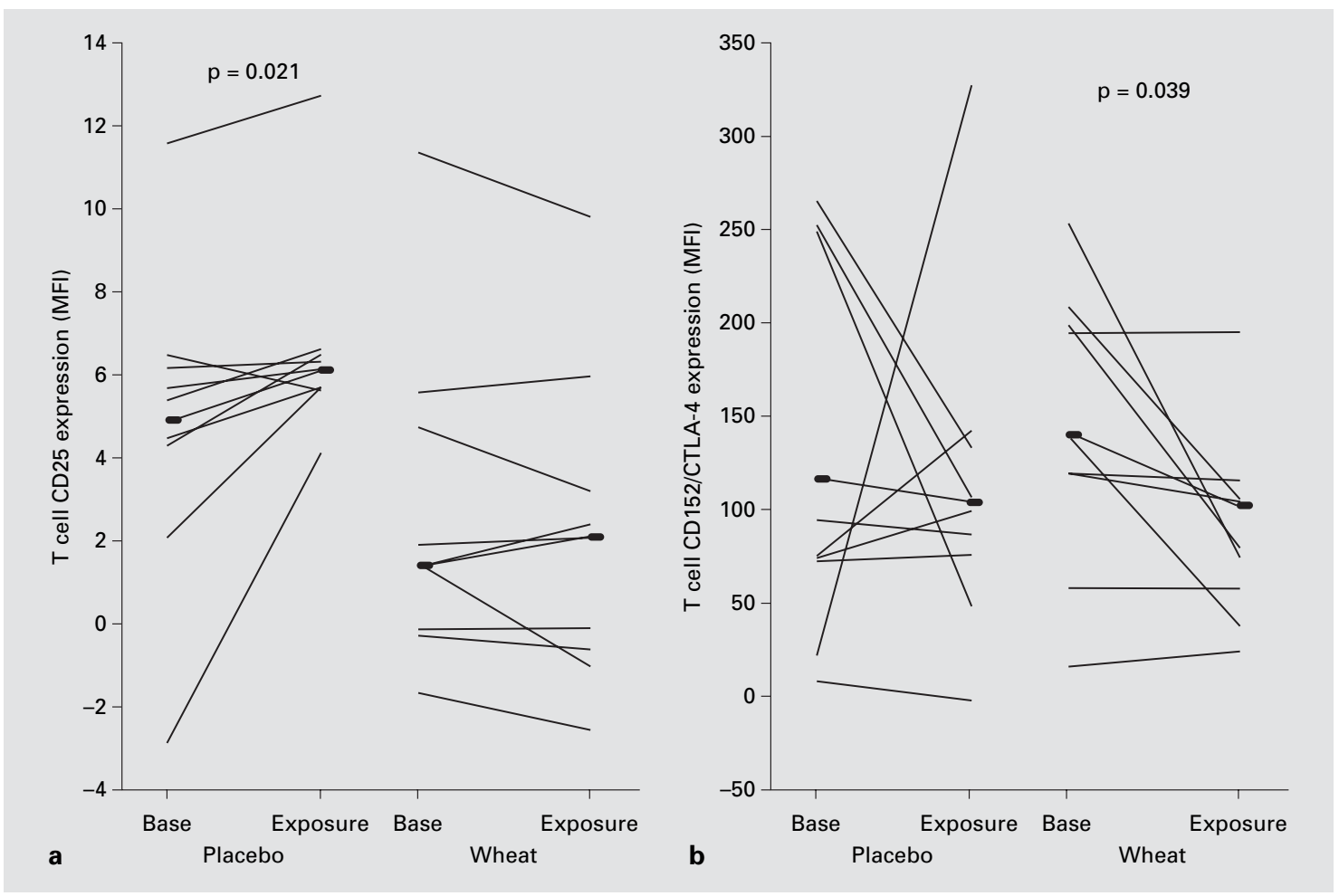

Fig. 4. Lower levels of CD25 and CD152 on T cells are detected after allergen provocation. a Differential change in CD25 expression on CD4+ T cells. Placebo upregulates CD25 expression. There is significantly less upregulation after allergen provocation. b Change in CD152 expression on CD4+ T cells. CD152 expression is reduced further during allergen provocation than with placebo. 
spirometry at baseline and before every ingested dose. There was no change in $\mathrm{FEV}_{1}$ or in $\mathrm{FEV}_{1} / \mathrm{FVC}$ throughout the provocations, even when considering only the 4 participants that had asthma (data not shown). Response of participants was evaluated by rhinometry at baseline and before every ingested dose. The minimum nasal cross-sectional area during the provocation test expanded slightly when provoked with placebo (fig. 1a). The first provocation with allergen resulted in a significant reduction in the minimum nasal cross-sectional area (mean $0.77 \pm 0.1 \mathrm{~cm}^{2}$ ) compared with baseline (mean $0.78 \pm$ $0.2 \mathrm{~cm}^{2} ; \mathrm{p}=0.013$ ) and compared with the dilated nostrils after the first provocation with placebo (mean $0.93 \pm$ $\left.0.2 \mathrm{~cm}^{2} ; \mathrm{p}=0.045\right)$.

Blood basophils were identified as Lin 1- HLA DRCD123+ cells (fig. 2a) at baseline or $30 \mathrm{~min}$ after the final provocation dose (fig. 1b). After placebo provocation, blood basophil numbers remained constant at 2,152 \pm 890 at baseline and at 2,164 $\pm 1,000$ (n.s., $\mathrm{n}=8$ ) and decreased from $2,146 \pm 740$ to $1,705 \pm 790$ after the allergen challenge ( $p=0.034$, $t$ test, $n=8)$. Serum tryptase was measured at baseline and $30 \mathrm{~min}$ after the highest dose. There was no change in serum tryptase from baseline to allergen exposure, but a significant decrease after exposure to placebo. The exposure/baseline ratio was significantly higher for allergen $(1.05 \pm 0.16)$ than for placebo $(0.92 \pm 0.09 ; \mathrm{p}=0.021, \mathrm{n}=9)$, and the difference in exposure/baseline was significantly higher for allergen $(0.01 \pm 0.7)$ than for placebo $(-0.05 \pm 0.67 ; p=0.011)$. Urine NMH is an inflammatory marker used to objectively diagnose food allergy. The NMH content of urine increased significantly after allergen exposure (10.37 \pm $3.4 \mu \mathrm{g} \mathrm{MH} / \mathrm{mmol}$ creatinine at baseline to $13.79 \pm$ $3.3 \mu \mathrm{g} \mathrm{MH} / \mathrm{mmol}$ creatinine after exposure; $\mathrm{p}=0.017$, $\mathrm{n}=8$ ), whereas the increase was not significant after placebo ingestion $(11.81 \pm 3.8$ to $13.49 \pm 4.4 \mu \mathrm{g} \mathrm{MH} / \mathrm{mmol}$ creatinine; n.s., $\mathrm{n}=8$ ).

\section{Blood DC Tolerize in Response to Provocation and}

Express Less CXCR4 after Allergen Provocation

The number of blood DC2 identified as Lin 1- HLA $\mathrm{DR}+\mathrm{CD} 11 \mathrm{a}^{\mathrm{dim}} \mathrm{CD} 123^{\text {bright }}$ cells (fig. 2b, 3a) decreased after exposure to allergen (at baseline 409 cells, IQR 363 761; after exposure 275 cells, IQR 195-469; $\mathrm{p}=0.001$, $\mathrm{n}=16$ ) and placebo (at baseline 442 cells, IQR 326-666; after exposure 260 cells, IQR 235-310), but there was no change in DC1 (Lin 1- HLA DR + CD1 $1 a^{\text {bright }}$ CD123 ${ }^{\mathrm{dim}}$ ) numbers detected (at baseline $650 \pm 244$ cells; after exposure $683 \pm 253$ cells; $n=16$ ). HLA DR expression (fig. 2b) on DC identified as CD14- HLA DR+ monocytic cells (fig. 2c) was reduced after either exposure - baseline mean fluorescence intensity (MFI) 153, IQR 114-204, and exposure MFI 126, IQR 100-182 ( $\mathrm{p}=0.001, \mathrm{n}=18)$. There was no difference between allergen and placebo provocations. Expression of CXCR 4 (fig. 2c) on DC identified as CD14- HLA DR+ monocytic cells was reduced significantly after allergen exposure (baseline MFI 288, IQR 232-321, and exposure MFI 246, IQR 192-268; $\mathrm{p}=0.05, \mathrm{n}=9$ ), but not after placebo exposure (baseline MFI 240, IQR 223-298, and exposure MFI 266, IQR 220-268). CCR5 could not be detected on CD14- HLA $\mathrm{DR}+$ cells (data not shown).

\section{Blood T Cells Express Less CD25 and CD152 (CTLA4) after Allergen Provocation than after Placebo Exposure}

CD4+ T cell expression of CD25 (fig. 2d, 3a) was elevated after placebo exposure (baseline MFI 4.9, IQR 4.35.6, and exposure MFI 6.1, IQR 5.7-6.5; $\mathrm{p}=0.021, \mathrm{n}=$ 9) but only marginally after allergen provocation (baseline MFI 4.8, IQR 3.7-7.8, and exposure MFI 5.4, IQR $3.5-6.4$; n.s., $\mathrm{n}=9$ ). The decrease of CD25 expression after allergen exposure compared with placebo was significant (MFI of $-0.50 \pm 1$ and $1.77 \pm 2.3$ for allergen and placebo, respectively; $p=0.024, n=9$ ). CD152 (fig. $3 b)$ measured on the same cells (CD4+) was downregulated after allergen provocation (baseline MFI $140 \pm 82$, exposure MFI $102 \pm 70 ; p=0.039, n=9$ ), but less after placebo exposure (baseline MFI $116 \pm 92$, exposure MFI $104 \pm 55$; n.s., $n=9$ ).

The expression of HLA DR as activation marker and CD27, thought to be a Th1 marker [13], did not vary between baseline and exposure, or between allergen and placebo (data not shown). The ratio of MT1/MT2 cells (MT1 is CD62L+CD11a dim , MT2 is CD62L-CD11 a bright) on CD4+ CD45RA- memory T cells [11] did not vary between baseline and exposure, or between allergen and placebo (data not shown).

\section{Discussion}

We have exposed 9 persons sensitized to inhaled flour and diagnosed with asthma or rhinitis to their respiratory allergen in a DBPCFC to investigate whether ingestion of flour allergen results in clinical symptoms in the respiratory tract. Early parameters of the cellular immune response were measured to investigate the processes by which the allergen was detected by the immune system and which reactions are critical. 
There were as many symptoms with placebo as with allergen. The exposure did not result in severe symptoms or side effects. The significant increase in urinary $\mathrm{NMH}$ and serum tryptase (compared with levels after exposure) and the decrease in blood basophils and nasal volume after ingestion of allergen compared with placebo suggest a specific response to ingested allergen. Rhinitis is among the frequent clinically detectable responses to a food challenge [14]. The challenge utilized a wide range of amounts of allergen $(0.5-50 \mathrm{~g})$ compared with regimes where the maximal challenge dose was $8 \mathrm{~g}$ protein [15]. However, in accordance with the conclusions in the previous study, reduction in the nasal volume was significant at the lowest concentration of wheat. Responses to provocation with food allergens tend to occur at the lowest dose given, rather than as a dose response. Severity did not increase as the amount of challenge food increased [15]. This suggests that there is a cross-reactivity between the organ systems, as is well documented by the cross-reactivity in allergy to birch pollen and apple $[4,5]$ and that of latex and bananas, kiwis and other fruit [2]. The only clinical response to ingested allergen was a decrease in nasal volume after the first dose of allergen. This may be because most participants (7/9) had been diagnosed with rhinitis, or because the nasopharyngeal region is the first part of the respiratory tract to come into contact with a typically airborne allergen and is populated with immune sentries (resulting in edema) when a large dose of allergen is delivered to the gastrointestinal tract. Rhinitis has previously been shown to be the most frequent respiratory symptom in DBPCFC [14]. The response in the nose was supported by (1) the detection of the metabolite of histamine, $\mathrm{NMH}$ in urine and a clinical test used to monitor gastrointestinal allergy [16], which was elevated at baseline (10 $\pm 4 \mu \mathrm{g} / \mathrm{m} M$ creatinine) compared with reference values of a normal population $(5.2 \pm 2.4 \mu \mathrm{g} / \mathrm{m} M$ creatinine) [12] and increased significantly after exposure to allergen, and (2) decreased blood basophil numbers after allergen exposure. Part of the increase in NMH may be due to histamine released in the stomach to digest the large dose ingested. Reduction in basophil numbers may be due to recruitment of basophils at the site of allergen exposure, which has been documented during challenges in the nose [17]. During the same time, serum tryptase decreased significantly only after placebo exposure, but remained unaltered after allergen exposure. This and elevated NMH suggest that there is an ongoing subclinical allergic response in flour-allergic persons that are constantly exposed to baked and raw allergen as part of their diet (anecdote: 'I can tell whether something is baked properly') and that they are under constant oral immunotherapy.

Enumeration of $\mathrm{pDC}$ and $\mathrm{mDC}$ has shown that people with atopic disease and controls have fewer pDC than mDC [18-21]. Previous work has shown that exposure to the relevant allergen in the lung of asthmatics recruits $\mathrm{mDC}$ from the circulation [22] and that after allergen provocation, $\mathrm{pDC}[6]$ and $\mathrm{mDC}$ [23] accumulate in the nose and lung, respectively. Only the latter study sought to identify both $\mathrm{mDC}$ and $\mathrm{pDC}$. The papers detecting $\mathrm{mDC}$ leaving the circulation [22] and showing an accumulation of mDC, but not of pDC [23], complement each other to suggest that $\mathrm{mDC}$ are recruited to the lung during local/inhalative allergen exposure. We have enumerated $\mathrm{mDC}$ and $\mathrm{pDC}$ at baseline and after a DBPCFC and found that only $\mathrm{pDC}$ were recruited from the circulation after provocation in the gastrointestinal tract, which is thought to be very tolerogenic $[24,25]$. The depletion was associated with a decrease in DC HLA DR expression characteristic for tolerizing DC [26]. The suggestion that pDC recruited during the allergen exposure have a tolerogenic function is supported by the observation that participants in the study reported similar symptoms with allergen as they did with placebo. In a murine model of asthma, $\mathrm{pDC}$ have been shown to be essential for preventing asthmatic reactions to harmless inhaled antigen [27]. The chemokine receptor profile of $\mathrm{mDC}$ and $\mathrm{pDC}$ is similar and included CXCR4 [28]; however, only pDC migrate in response to stromal-derived factor 1 (the ligand for CXCR4) in vitro. The present finding that $\mathrm{mDC}$ numbers remain constant while $\mathrm{pDC}$ numbers and the level of expression of CXCR4 on DC decrease during an allergic stimulus is consistent with the mechanism in which pDC are selectively recruited from the circulation by the allergic stimulus involving stromal-derived factor 1 . Our observations support previous reports [22, 29] that DC are recruited from the circulation in response to appropriate allergic signals from the environment and expand on it by showing that also pDC can selectively be recruited from the circulation by exposure to a relevant antigen where few clinical symptoms are reported. Thus, whilst $\mathrm{mDC}$ may be crucial for the generation of an allergic response [30], our results are consistent with the observation that $\mathrm{pDC}$ may be even more important in maintaining tolerance to harmless antigens [27], and the balance between the two subsets could determine how the immune response develops.

There appeared to be a general activation of $\mathrm{T}$ cells by placebo, as documented by the increase in expression of CD25 on CD4+ T cells. In contrast, expression of CD25 
on $\mathrm{T}$ cells was reduced after allergen compared with placebo exposure. This is consistent with a model in which $\mathrm{CD} 25+\mathrm{T}$ cells, together with tolerized $\mathrm{pDC}$, are recruited to the site of allergic exposure. The observation that the expression of CD152/CTLA-4 is reduced is consistent with a model in which these potentially regulatory $\mathrm{T}$ cells [7] leave the circulation after allergen stimulation (a strong, specific stimulus that could be mediated through IgE/FceRI expressed on, amongst others, pDC) [31] and less so after placebo stimulation (a diffuse stimulus). Blocking CD152 on regulatory T cells has inhibited their regulatory activity [7]. The time frame for expression of CD27 HLA DR on T cells and MT1 and MT2 markers [11] may have been suboptimal in this study.

Allergic persons with rhinitis, asthma or both respond to relevant ingested allergen. Exposure to allergen could be differentiated from placebo exposure by rhinometry, blood basophil, serum tryptase and urine NMH content. In addition, the blood concentration of $\mathrm{pDC}$ as well as the expression of HLA DR on DC decreased after each challenge, supporting a drain from the circulation as well as tolerization of DC. Expression of CXCR4 on DC was reduced only after allergen challenge. Change in $\mathrm{T}$ cell expression of CD25 and CD152 was consistent with recruitment of activated and regulatory $\mathrm{T}$ cells from the circulation to the site of allergen exposure. The reduction in circulation of $\mathrm{pDC}$ and $\mathrm{T}$ cells with tolerizing phenotype may explain why there was no allergic response to the provocation beyond the clinical response after the first dose. In contrast to the cross-reacting allergens that frequently elicit gastrointestinal and oral responses, wheat was both respiratory and the gastrointestinal allergen. Amongst the markers measured, blood basophil numbers are candidates for objective measurements of the response in a DBPCFC.

\section{Acknowledgements}

The technical assistance of Anne Marie Toft, Birthe Gahrn Mains and Ingrid Grothe is appreciated. The project was financed by the Danish Ministry for Food, Agriculture and Fisheries, the Velux and Lundbeck foundations, the Danish Allergy Research Center and the Research Foundation of Aarhus University.

\section{References}

1 Biagini RE, MacKenzie BA, Sammons DL, et al: Evaluation of the prevalence of anti-wheat, anti-flour dust, and anti-alpha-amylase specific $\mathrm{IgE}$ antibodies in US blood donors. Ann Allergy Asthma Immunol 2004;92:649-653.

2 Moneret-Vautrin DA, Morisset M: Adult food allergy. Curr Allergy Asthma Rep 2005;5:8085.

3 Kaukinen K, Turjanmaa K, Maki M, et al: Intolerance to cereals is not specific for coeliac disease. Scand J Gastroenterol 2000;35:942946.

4 Kanny G, Moneret-Vautrin DA, Flabbee J, Beaudouin E, Morisset M, Thevenin F: Population study of food allergy in France. J Allergy Clin Immunol 2001;108:133-140.

5 Bolhaar ST, Tiemessen MM, Zuidmeer L, et al: Efficacy of birch-pollen immunotherapy on cross-reactive food allergy confirmed by skin tests and double-blind food challenges. Clin Exp Allergy 2004;34:761-769.

6 Jahnsen FL, Lund-Johansen F, Dunne JF, Farkas L, Haye R, Brandtzaeg P: Experimentally induced recruitment of plasmacytoid $\left(\mathrm{CD} 123^{\text {high }}\right)$ dendritic cells in human nasal allergy. J Immunol 2000; 165:4062-4068.

7 Birebent B, Lorho R, Lechartier H, et al: Suppressive properties of human CD4+CD25+ regulatory $\mathrm{T}$ cells are dependent on CTLA-4 expression. Eur J Immunol 2004;34:34853496 .
8 Bock SA, Sampson HA, Atkins FM, et al: Double-blind, placebo-controlled food challenge (DBPCFC) as an office procedure: a manual. J Allergy Clin Immunol 1988;82:986-997.

9 Pedersen B, Dahl R, Larsen BB, Venge P: The effect of salmeterol on the early- and late-phase reaction to bronchial allergen and postchallenge variation in bronchial reactivity, blood eosinophils, serum eosinophil cationic protein, and serum eosinophil protein X. Allergy 1993; 48:377-382.

10 Hilberg O: Objective measurement of nasal airway dimensions using acoustic rhinometry: methodological and clinical aspects. Allergy 2002;57(suppl 70):5-39.

11 Mitra DK, De Rosa SC, Luke A, et al: Differential representations of memory $T$ cell subsets are characteristic of polarized immunity in leprosy and atopic diseases. Int Immunol 1999; 11:1801-1810.

12 Winterkamp S, Weidenhiller M, Wilken V, et al: Standardised evaluation of urinary excretion of N-tele-methylhistamine in different periods of age in a healthy population. Inflamm Res 2003;52(suppl 1):S57-S58.

13 Lucey DR, Clerici M, Shearer GM: Type 1 and type 2 cytokine dysregulation in human infectious, neoplastic, and inflammatory diseases. Clin Microbiol Rev 1996;9:532-562.
14 James JM, Bernhisel-Broadbent J, Sampson HA: Respiratory reactions provoked by double-blind food challenges in children. Am J Respir Crit Care Med 1994; 149:59-64.

15 Perry TT, Matsui EC, Conover-Walker MK, Wood RA: Risk of oral food challenges. J Allergy Clin Immunol 2004;114:1164-1168.

16 Stephan V, Zimmermann A, Kuhr J, Urbanek $\mathrm{R}$ : Determination of $\mathrm{N}$-methylhistamine in urine as an indicator of histamine release in immediate allergic reactions. J Allergy Clin Immunol 1990;86:862-868.

17 Nouri-Aria KT, Irani AM, Jacobson MR, et al: Basophil recruitment and IL-4 production during human allergen-induced late asthma. J Allergy Clin Immunol 2001;108:205-211.

18 Uchida Y, Kurasawa K, Nakajima H, et al: Increase of dendritic cells of type 2 (DC2) by altered response to IL-4 in atopic patients. $\mathrm{J}$ Allergy Clin Immunol 2001;108:1005-1011.

19 Reider N, Reider D, Ebner S, et al: Dendritic cells contribute to the development of atopy by an insufficiency in IL-12 production. J Allergy Clin Immunol 2002;109:89-95.

20 Matsuda H, Suda T, Hashizume H, et al: Alteration of balance between myeloid dendritic cells and plasmacytoid dendritic cells in peripheral blood of patients with asthma. Am J Respir Crit Care Med 2002;166:1050-1054. 
21 Hagendorens MM, Ebo DG, Schuerwegh AJ, et al: Differences in circulating dendritic cell subtypes in cord blood and peripheral blood of healthy and allergic children. Clin Exp Allergy 2003;33:633-639.

22 Upham JW, Denburg JA, O’Byrne PM: Rapid response of circulating myeloid dendritic cells to inhaled allergen in asthmatic subjects. Clin Exp Allergy 2002;32:818-823.

23 Jahnsen FL, Moloney ED, Hogan T, Upham JW, Burke CM, Holt PG: Rapid dendritic cell recruitment to the bronchial mucosa of patients with atopic asthma in response to local allergen challenge. Thorax 2001;56:823-826.
24 Sudo N, Sawamura S, Tanaka K, Aiba Y, Kubo C, Koga Y: The requirement of intestinal bacterial flora for the development of an IgE production system fully susceptible to oral tolerance induction. J Immunol 1997; 159: 1739-1745.

$25 \mathrm{Kim} \mathrm{JH}$, Ohsawa M: Oral tolerance to ovalbumin in mice as a model for detecting modulators of the immunologic tolerance to a specific antigen. Biol Pharm Bull 1995;18:854-858.

26 Steinbrink K, Wolfl M, Jonuleit H, Knop J Enk AH: Induction of tolerance by IL-10-treated dendritic cells. J Immunol 1997; 159:47724780.

27 de Heer HJ, Hammad H, Soullie T, et al: Essential role of lung plasmacytoid dendritic cells in preventing asthmatic reactions to harmless inhaled antigen. J Exp Med 2004;200:89-98.
28 Penna G, Sozzani S, Adorini L: Cutting edge: selective usage of chemokine receptors by plasmacytoid dendritic cells. J Immunol 2001; 167 : 1862-1866.

29 Smits HH, de Jong EC, Wierenga EA, Kapsenberg ML: Different faces of regulatory DCs in homeostasis and immunity. Trends Immunol 2005;26:123-129.

30 Lambrecht BN, Hammad H: Myeloid dendritic cells make it to the top. Clin Exp Allergy 2002;32:805-810.

31 Novak N, Allam JP, Hagemann T, et al: Characterization of FcepsilonRI-bearing CD123 blood dendritic cell antigen-2 plasmacytoid dendritic cells in atopic dermatitis. J Allergy Clin Immunol 2004; 114:364-370. 